\title{
Foreign Direct Investment, Trade and Economic Growth in Taiwan
}

\author{
Hsia Sung-Ming \\ School of Business Nanjing University, Nanjing, China \\ Email: garyhsia2006@gmail.com
}

Received November 6, 2013; revised December 6, 2013; accepted December 13, 2013

Copyright (C) 2014 Hsia Sung-Ming. This is an open access article distributed under the Creative Commons Attribution License, which permits unrestricted use, distribution, and reproduction in any medium, provided the original work is properly cited. In accordance of the Creative Commons Attribution License all Copyrights (C) 2014 are reserved for SCIRP and the owner of the intellectual property Hsia Sung-Ming. All Copyright (C) 2014 are guarded by law and by SCIRP as a guardian.

\begin{abstract}
Taiwan is the capital-open region. To understand the FDI, trade and economic growth should be one of the worthy studies on the question. This paper uses the data from 1978 to 2009 in Taiwan, and uses the VECM model to analyze the impact of foreign direct investment on economic growth in Taiwan. The results of the VECM model for FDI and economic growth in Taiwan have both the long-term existence of the cointegration relations and the reverse relationship.
\end{abstract}

\section{KEYWORDS}

\section{Economic Growth; Foreign Direct Investment (FDI); Vector Error Correction Model (VECM)}

\section{Introduction}

For policymakers, how to promote foreign trade and foreign investors for its direct investment to enhance rapid economic growth in home country, has been ruled by those who care about the important issues, due to the fact that foreign technological transfers bring technological diffusion and generate technological spillovers for local firms, and foreign investment is expected to increase and improve the existing stock of knowledge in the recipient economy through labor's human capital, skill acquisition and diffusion (Din [1]; Balasubramanyam et al. [2]; Borensztein et al. [3]).

With globalization spreads throughout the world, the foreign direct investment becomes more popular for multinational enterprises. In traditional and new economic theory, most governments have referred to incentives to create a suitable investment environment to attract foreign investment; the government's view is based on the amount of foreign investment to improve home country's employment, making the domestic labor income increase, thereby enhancing economic growth (Blomstrom, et al. [4]; Wacziarg [5]).

However, Taiwan is part of the global inter-regional capital openness. Understanding of the complex relation- ships on foreign investment, trade and economic growth is a topic worthy of study. Moreover, since its adoption of the policy relaxing and trade liberalization had been taken in the mid-1970s, after that, Taiwan's trade and FDI have been expanded at even higher rates. The advance literatures of endogenous growth models considered FDI that would contribute significantly to economic growth. On the other hand, the FDI maybe causes a negative impact on economic growth in developing countries, because FDI always induces more and more income inequality (Mansfield and Romeo [6]; Saltz [7]; Haddad and Harrison [8]; Eric and Joseph [9]).

This paper studies the dynamic relationship between export, FDI and economic growth in a time-series framework from 1978 to 2009. It is also important to highlight that the interaction among these variables is complex and each variable (GDP, labor, the stock of capital, net export and FDI) has a plausible theoretical foundation to affect the other variables. Without knowing the direction and pattern of mechanisms among these variables, it is important to investigate the relationship between these variables to correctly formulate policies in Taiwan. More generally, we seek to establish the causal link between FDI and economic growth, which might suggest important implications for development strategies for Taiwan. 
The rest of the paper is organized as follows. Section 2 describes data and methodology adopted in this study. Section 3 discusses the empirical results. And finally Section 4 concludes.

\section{Data and Results}

This paper explores the causal relationship between labor, capital, net export, FDI and GDP in both the short run and long run. The dataset consists of Taiwan observations on real GDP, the quantities of labor (L), gross capital formation as proxy for capital (K), net export (NX) the total volume of export minus total volume of import, and foreign direct investment (FDI). The data set is yearly and covers the periods 1978 to 2009. All data series are obtained from the Chinese National Statistics database $^{1}$.

\subsection{Stationary Tests}

The descriptive statistics are presented in Table 1. Time series univariate properties were examined using unit root tests: augmented Dickey and Fuller (ADF) test. In Table 2, although the ADF test suggests the presence of unit roots in levels, all the variables are stationary after first differencing. The choice of the lagged period, we follow the Akaike information criterion (AIC) test results suggest using a lag length of one ${ }^{2}$.

\subsection{Cointegration Test}

The cointegration analysis captures the dynamic relationship among the five variables. The multivariate cointegration test based on Johansen-Juselius's model is used to determine the long run relationship. Table 3 presents the Johansen cointegration test results among the variables with linear deterministic trend and one lag. The maximum eigenvalue test and trace test to establish the number of cointegrating vectors is reported in Table 3 .

\subsection{Granger-Causality Test}

According to representation theorem, if two variables are cointegrated then the Granger causality must exist in at least one direction. Results of Granger causality tests reported in Table 4 indicates that log (GDP) Granger causes log (FDI) from the Taiwanese data.

\section{Empirical Results}

Using a VECM for the period 1978 through 2009, the

\footnotetext{
${ }^{1}$ The Chinese National Statistics database website: http://ebas1.ebas.gov.tw/pxweb/Dialog/statfile1L.asp?lang=1\&strList= L.

${ }^{2}$ In order to choose the lagged period, we use the Akaike information criterion (AIC) and Schwartz's Bayesian Information Criterion (BIC) tests. The AIC suggest the using a lag length of one and the BIC suggest the using a lag length of two.
}

Tab le 1. Descriptive statistics.

\begin{tabular}{cccccc}
\hline & GDP & L & K & NX & FDI \\
\hline Mean & 9830.563 & 8829.125 & 1516835 & 0.872887 & 3293104 \\
Median & 11530.50 & 8977.500 & 1662122 & 0.835897 & 2360036 \\
Std Dev. & 5370.371 & 1365.360 & 872873.5 & 0.133343 & 3623575 \\
Skewness & -0.243576 & -0.270196 & -0.019827 & 1.151969 & 2.026481 \\
Kurtosis & 1.553719 & 1.976627 & 1.465336 & 3.770533 & 6.919643 \\
No & 32 & 32 & 32 & 32 & 32 \\
\hline
\end{tabular}

Table 2. Unit root tests with ADF in logarithm form (with trend and intercept).

\begin{tabular}{ccccc}
\hline Variables & $\begin{array}{c}\text { No. of } \\
\text { Lagged } \\
\text { Differences }\end{array}$ & $\begin{array}{c}\text { Test } \\
\text { Statistic }\end{array}$ & $\begin{array}{c}\mathbf{5 \%} \\
\text { Critical } \\
\text { Value }\end{array}$ & $\begin{array}{c}\text { 1\% Critical } \\
\text { Value }\end{array}$ \\
\hline $\log ($ GDP) & 1 & -4.168 & -3.568 & -4.296 \\
$\log (\mathbf{L})$ & 1 & -4.116 & -3.568 & -4.296 \\
$\log (\mathbf{K})$ & 1 & -3.811 & -3.568 & -4.296 \\
$\mathbf{L o g}(\mathbf{N X )}$ & 1 & -5.020 & -3.568 & -4.296 \\
$\log ($ FDI) & 1 & -5.056 & -3.595 & -4.356 \\
\hline
\end{tabular}

Table 3. Trace/maximum eigenvalue tests.

\begin{tabular}{ccc}
\hline NullHypothesis & Trace test & Maximal eigenvalue test \\
\hline None $^{*}$ & 95.65 & 41.80 \\
At most 1 $^{*}$ & 53.85 & 28.25 \\
At most 2 & 25.59 & 17.05 \\
\hline
\end{tabular}

Notes: "denotes $5 \%$ levels of significance respectively.

Table 4. Granger causality test among log (GDP) and log (FDI).

\begin{tabular}{ccc}
\hline & F-Statistics & Probability \\
\hline $\begin{array}{c}\text { Log(FDI) does not Granger Cause } \\
\text { Log(GDP) }\end{array}$ & 0.47112 & 0.49812 \\
$\begin{array}{c}\text { Log(GDP) does not Granger } \\
\text { Cause Log(FDI) }\end{array}$ & 4.37693 & 0.04562 \\
\hline
\end{tabular}

estimated results shown in Table 5, suggest that the long-run elasticity of the GDP to the labor is almost 1.54. In other words, a one percent deviation in the labor increases the GDP by $1.54 \%$. Accordingly, a one percent deviation in the capital increases the GDP by $1.14 \%$; a one percent deviation in the net export decreases the GDP by $0.405 \%$ and a one percent deviation in the FDI decreases the GDP by $0.144 \%$.

The variance decomposition technique for a period of 10 months ahead, presented in Table 6 indicates that the Taiwan economic growth is mainly affected by capital stock; almost $18 \%$ of its changes can be attributed to capital by the end of the period. The role of labor increases from $0.98 \%$ in the beginning of the period to 
Table 5. Vector error correction estimates: one lagged period.

\begin{tabular}{cc}
\hline CointegratingEq: & CointEq1 \\
\hline $\mathbf{L o g}(\mathbf{G D P})(-\mathbf{1})$ & 1.000 \\
$\mathbf{L o g}(\mathbf{L})(-\mathbf{1})$ & -1.54 \\
& {$[-2.64465]$} \\
$\mathbf{L o g}(\mathbf{K})(-1)$ & -1.14 \\
& {$[-10.2192]$} \\
$\log (\mathbf{N X})(-1)$ & 0.405 \\
& {$[2.82709]$} \\
$\log (\mathbf{F D I})(-1)$ & 0.144 \\
$\mathbf{C}$ & {$[2.29078]$} \\
\hline
\end{tabular}

[ ] represents t-statistics.

Table 6. Variance decomposition of GDP.

\begin{tabular}{ccccc}
\hline Period & $\log (\mathbf{K})$ & $\log (\mathbf{L})$ & $\log (\mathbf{N X})$ & $\log (\mathbf{F D I})$ \\
\hline $\mathbf{1}$ & 0.000000 & 0.000000 & 0.000000 & 0.000000 \\
$\mathbf{2}$ & 0.073501 & 0.981505 & 0.252318 & 0.103572 \\
$\mathbf{3}$ & 0.539861 & 2.764573 & 0.297183 & 0.348448 \\
$\mathbf{4}$ & 2.562617 & 4.658351 & 0.371477 & 1.176564 \\
$\mathbf{5}$ & 5.344570 & 6.637387 & 0.458806 & 2.167369 \\
$\mathbf{6}$ & 8.244582 & 8.598057 & 0.536627 & 3.136633 \\
$\mathbf{7}$ & 10.99610 & 10.40226 & 0.599489 & 4.026049 \\
$\mathbf{8}$ & 13.47663 & 11.98447 & 0.649193 & 4.807004 \\
$\mathbf{9}$ & 15.64412 & 13.34225 & 0.688571 & 5.473990 \\
$\mathbf{1 0}$ & 17.50822 & 14.49779 & 0.719864 & 6.037133 \\
\hline
\end{tabular}

$14.5 \%$ at the end of the period. However, the contribution of NX increases from $0.25 \%$ in the first month to $0.71 \%$ at the end of the period. Finally, the contribution of FDI increases from $0.10 \%$ in the first month to $6.03 \%$ at the end of the period.

\section{Conclusions}

The study has used annual data from 1978 to 2009 to examine the impact of FDI on economic growth in Taiwan. In order to understand the relationship among FDI, trade and economic growth, we adopt a time-series framework, including 1) the long-run association between FDI and economic growth and Taiwan's fundamentals through cointegration technique, 2) causality test among the FDI and economic growth rate, and 3) estimation of the longrun and short-run elasticity of the Taiwanese economic growth in response to deviation in labor, capital, net export, and FDI.

The cointegration analysis reveals the existence of long-run relationship between FDI and economic growth. The empirical results suggest that the model is cointegrated and at least one cointegration vector exists among the Taiwan. The Granger Causality test indicates that the causality runs from the GDP to FDI. Moreover, according to the conclusions of VECM model, there is nothing that exists between FDI and economic growth in an inverse relationship.

Accordingly, for host government, in order to enhance Taiwan's economic growth, the primary purpose is not to improve the proportion of foreign investment, but for the local manufacturers to enhance the incentives for capital investment (for example: investment subsidies rises, loan rates declines and so on).

\section{REFERENCES}

[1] D. Muslehud, "Export Processing Zone and Backward Linkages," Journal of Development Economics, Vol. 43, No. 2, 1994, pp. 369-385. http://dx.doi.org/10.1016/0304-3878(94)90014-0

[2] V. N. Balasubramanyam, M. A. Salisu and D. Sapsford, "Foreign Direct Investment and Growth in EP and IS Countries,” Economic Journal, Vol. 106, No. 434, 1996, pp. 92-105. http://dx.doi.org/10.2307/2234933

[3] E. Borensztein, J. de Gregorio and J. W. Lee, "How Does Foreign Direct Investment Affect Growth,” Journal of International Economics, Vol. 45, No. 1, 1998, pp. 115-135. http://dx.doi.org/10.1016/S0022-1996(97)00033-0

[4] M. Blomström, A. Kokko and M. Zejan, "Host Country Competition and Technology Transfer by Multinationals," Weltwirtschaftliches Archives, Vol. 130, No. 3, 1994, pp. 521-533. http://dx.doi.org/10.1007/BF02707611

[5] R. Wacziarg, "Measuring the Dynamic Gains from Trade," World Bank Economic Review, Vol. 15, No. 3, 2001, pp. 393-429. http://dx.doi.org/10.1093/wber/15.3.393

[6] E. Mansfield and A. Romeo, "Technology Transfer to Overseas Subsidiaries by US-Based Firms,” Quarterly Journal of Economics, Vol. 95, No. 4, 1980, pp. 737-750. http://dx.doi.org/10.2307/1885489

[7] I. Saltz, "The Negative Correlation between Foreign Direct Investment and Economic Growth in the Third World: Theory and Evidence," Rivista Internazionale di Scienze Economichee Commerciali, Vol. 39, 1992, pp. 617-633.

[8] M. Haddad and A. Harrison, "Are There Positive Spillovers from Direct Foreign Investment? Evidence from Panel Data for Morocco," Journal of Development Economics, Vol. 42, No. 1, 1993, pp. 51-74. http://dx.doi.org/10.1016/0304-3878(93)90072-U

[9] E. F. Oteng-Abayie and J. M. Frimpong, "Bounds Testing Approach to Cointegration: An Examination of Foreign Direct Investment Trade and Growth Relationships," American Journal of Applied Sciences, Vol. 3, No. 11, 2006, pp. 2079-2085.

http://dx.doi.org/10.3844/ajassp.2006.2079.2085 